\title{
Metals Uptake by Sagittaria montevidensis in Contaminated Riparian Area of Matanza-Riachuelo River (Argentina)
}

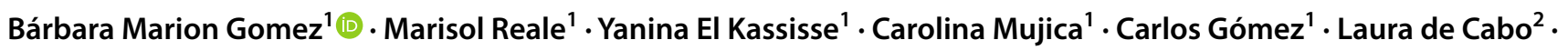 \\ Valeria Rodríguez Salemi ${ }^{1}$
}

Received: 12 August 2020 / Accepted: 31 October 2020 / Published online: 10 November 2020

(c) Springer Nature Switzerland AG 2020

\begin{abstract}
The objective of this study was to evaluate the accumulation and uptake of $\mathrm{Cr}, \mathrm{Zn}, \mathrm{Cu}, \mathrm{Ni}$ and $\mathrm{Pb}$ in Sagittaria montevidensis growing in highly contaminated riparian soils of Matanza Riachuelo Basin (MRB). It is a native and very abundant riparian plant exposed to heavy metal contamination. Samples of $S$. montevidensis, rhizosphere riparian soil and water were collected at three sites in the lower MR basin. The accumulation and the level of translocation of $\mathrm{Cr}, \mathrm{Zn}, \mathrm{Cu}, \mathrm{Ni}$ and $\mathrm{Pb}$ in this species were determined. The soils were found to be the main reservoirs of metals ( $2225 \mathrm{mg} \mathrm{Cr} \mathrm{kg}^{-1} \mathrm{~d}_{\text {.w. }}$, $367 \mathrm{mg} \mathrm{Cu} \mathrm{kg}^{-1}$ d.w., $61 \mathrm{mg} \mathrm{Ni} \mathrm{kg}^{-1}$ d.w., $239 \mathrm{mg} \mathrm{Pb} \mathrm{kg}^{-1}$ d.w., and $1495 \mathrm{mg} \mathrm{Zn} \mathrm{kg}^{-1}$ d.w.). All studied metals were uptaken, but $\mathrm{Zn}$ and Cu were the most accumulated metals $\left(426 \pm 28 \mathrm{mg} \mathrm{kg}^{-1}\right.$ d.w. and $129 \pm 28 \mathrm{mg} \mathrm{kg}^{-1}$ d.w., respectively). $S$. montevidensis was an accumulator species for $\mathrm{Cu}$ and $\mathrm{Ni}$ (Translocation Factor (TF) $>1$ ) and it showed an exclusionary behavior ( $\mathrm{TF}<1)$ for $\mathrm{Cr}, \mathrm{Pb}$, and $\mathrm{Zn}$. Cu was mostly accumulated in the aerial biomass. The rest of the metals analyzed were mainly accumulated in the roots. The analyzed plant specimens did not show signs of stress, having completed their phenological states. This native species shows high tolerance of metals. Then the preservation and revegetation of this species in the riparian areas constitute a sustainable alternative for ecological restoration.
\end{abstract}

Keywords Riverbank degradation · Contaminated riparian soils · Bioconcentration factor · Translocation · Native plants . Heavy metals

\section{Introduction}

The Matanza Riachuelo River (Buenos Aires, Argentina) is considered one of the most polluted rivers of Latin America [1] and drains into the binational estuary Río de la Plata, which represents the main source of drinking water for Buenos Aires city and environs [2]. This temperate lowland river is $64 \mathrm{~km}$ in length and is the main course of the Matanza-Riachuelo Basin (MRB), a densely populated basin of more 3.5 million inhabitants that comprises approximately $2250 \mathrm{~km}^{2}$. This basin has been contaminated since the beginning of the XIX century by salting and tanning plants [3]. Among the industries currently installed are tanneries, electroplating and chemical factories that use heavy metals in their processes such as chrome $(\mathrm{Cr})$, copper $(\mathrm{Cu})$, zinc $(\mathrm{Zn})$, lead $(\mathrm{Pb})$ and nickel $(\mathrm{Ni})$, among others.

Heavy metals are one of the groups of environmental pollutants of concern, mainly because of their persistence and the low concentrations at which they can manifest their toxic effects [4], resulting in a danger to both human health and ecosystems [5]. In aquatic systems, they eventually become associated with particulate matter settling

Bárbara Marion Gomez and Marisol Reale contributed equally to this work.

Bárbara Marion Gomez, barbaramarion@gmail.com | 'Subgerencia Centro de Tecnología del Uso del Agua, Instituto Nacional del Agua, Au. Ezeiza-Cañuelas, tramo Jorge Newbery Km 1,620, B1804, Ezeiza, Buenos Aires, Argentina. ${ }^{2}$ CONICET - Museo Argentino de Ciencias Naturales "Bernardino Rivadavia” (MACN-CONICET), Av. Ángel Gallardo 470, C1405DJR Ciudad Autónoma de Buenos Aires, Argentina. 
and accumulating in bottom sediments. Some studies have established that most aquatic rooted plants pick up metals primarily from the pore water of the sediment [6]. The roots, stems, leaves, fruits and seeds of most plants, present different levels of concentration and accumulation of heavy metals [7]. When the sediment is the source of heavy metals the levels usually decrease in this order: roots $>$ stems $>$ leaves $>$ fruits $>$ seeds. In general, the tolerance mechanisms are different among different plant species and they will depend on the metal and its concentration.

Those plants that are adapted to and thrive in soils rich in heavy metals are known as metallophytes $[8,9]$. In turn, metallophytes can be divided into three categories: metal excluders, metal indicators and metal hyperaccumulators [8]. In the particular case of metal excluders, these accumulate metal in the roots, restricting its translocation to the aerial part [9-11]. Such plants have a low potential for metal extraction but may be efficient for phytostabilization purposes $[8,9]$.

The distribution and behavior of many aquatic plants are often correlated with water quality [12]. They can accumulate contaminants at a level higher than the content in the environment [13]. The emergent aquatic macrophytes of the genus Sagittaria (Alismataceae), have a wide worldwide distribution. They can be found in America, Europe, and Asia [14-16]. A particularity of this genus is its phenotypic plasticity [14], it possesses striking variability within and among populations in both vegetative structures, particularly leaf shape $[17,18]$. The species Sagittaria montevidensis Cham. and Schltdl. (Fig. 1), selected for this study, is native to South America, has rhizomes, and it can reach up to $1.5 \mathrm{~m}$ in height [19]. Feijoó and Lombardo [20] and Lopez Van Oosterom et al. [21] recorded this species in different streams of the Pampas region and in particular Basílico et al. [22] did so for the MRB. This species is very abundant in the most degraded sites of the MRB. Despite the fact that it is widely distributed in environments with different degrees of anthropic impact on rivers in South

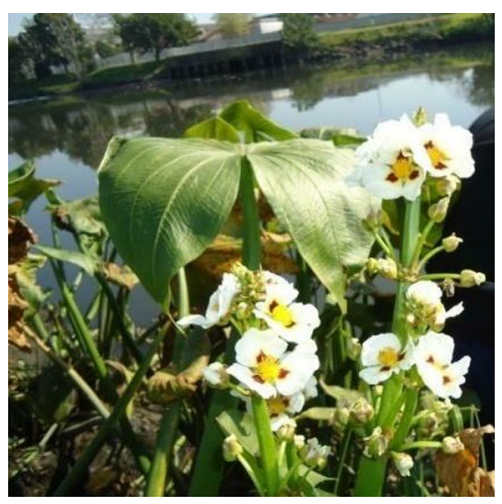

Fig. 1 Collected specimen of Sagittaria montevidensis
America, there is a lack of studies evaluating the potential of S. montevidensis for use in phytoremediation [23]. In this context, the objective of this study was to evaluate the accumulation and uptake of $\mathrm{Cr}, \mathrm{Zn}, \mathrm{Cu}, \mathrm{Ni}$ and $\mathrm{Pb}$ in $S$. montevidensis growing in highly contaminated riparian soils of MRB.

\section{Material and Methods}

\subsection{Area of Study}

Three sites located in the river banks of the highest urban and industrial concentration area of MRB were chosen for this study. The sites were Puente Vittorino de la Plaza, Puente Uriburu and Puente Bosch (Fig. 2). They record the highest historical values of heavy metals in sediment reported by the Autoridad de Cuenca Matanza Riachuelo [24] in its hydrological data base [25].

\subsection{Sample Collection}

S. montevidensis was present in all sampled sites. From each place, an isolated adult S. montevidensis individual of similar size was collected along with its respective belowground biomass and rhizospheric soil. Also, river surface water samples were taken near the site from which the plants were collected. Both water and riparian soil samples were collected in polyethylene containers previously washed with $50 \% \mathrm{HNO}_{3}$ and rinsed with deionized water. The bottles with the water samples were preserved in the field with $\mathrm{HNO}_{3}$ at $\mathrm{pH}<2$. The sampling was carried out on August 26, 2016.

\subsection{Sample Analysis}

Once in the laboratory, the plants were rinsed with tap water to remove any remaining soil and finally with deionized water. Each plant was divided into: belowground part, aerial part (stem and leaves) and flowers. The relationship between the subway part and the aerial one was 70-30, respectively. The clean and dry plant tissue was placed in a stove at $60^{\circ} \mathrm{C}$ for one week. It was taken to constant weight and ground to a fine and homogeneous powder with a porcelain mortar.

The samples of water and soil were kept at $4{ }^{\circ} \mathrm{C}$ until analysis.

The total metals contents ( $\mathrm{Cr}, \mathrm{Pb}, \mathrm{Zn}, \mathrm{Cu}$ and $\mathrm{Ni}$ ) were determined in triplicate in plant tissues, water and soil. The acid digestion was performed by microwave following the protocol established by the EPA 3015, 3051 and 3052 respectively [26-28]. After digestion, the determination of heavy metals was performed by atomic absorption

SN Applied Sciences 


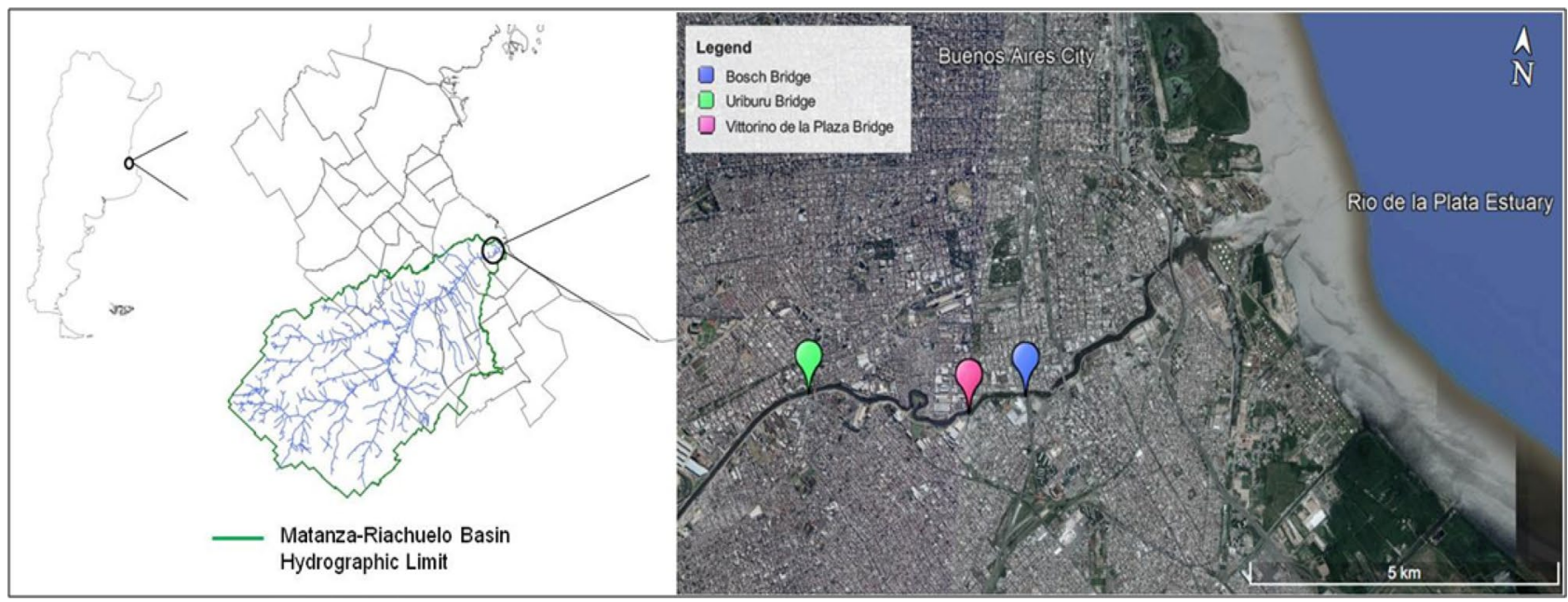

Fig. 2 Map with the location of the sampling sites in the lower Matanza-Riachuelo Basin, Buenos Aires, Argentina

spectrophotometry by the flame method following standardized protocols except for $\mathrm{Pb}$ in water which was determined by graphite furnace [29]. The results of metal concentration in soil were expressed as a percentage of dry weight and the water content of the soils samples was determined by measuring weight loss after drying to $105^{\circ} \mathrm{C}$ up to constant weight. Traceable certified standards for the analysis of metals were from Merck, Inc. (1000 $\mathrm{mg} \mathrm{L}^{-1}$ standard stock solutions, in $\mathrm{HNO}_{3}$, traceable to National Institute of Standards and Technology (NIST), USA) and used the ULTRAcheck Blind Quality Control Check Standards (certified by ULTRA Scientific and traceable to NIST). Chemicals for sample treatment or analysis of major matrix components were analytical grade. All the glass material used was washed with $50 \% \mathrm{HNO}_{3}$ and rinsed with deionized water.

\subsection{Bioaccumulation and Translocation Analysis}

The bioconcentration factor (BCF) indicates the efficiency of a plant species in accumulating a metal into its tissues from the surrounding environment and it is the ratio between the concentration of the target metal in the plant harvested tissue and the concentration of the same metal in the soil (substrate) [8]. BCF was calculated as $B C F=C_{t} / C_{s}$, where $C_{t}=$ Heavy metal concentration in plant tissue (roots, stem, leaves and flowers) ( $\mathrm{mg} \mathrm{kg}^{-1}$ d.w.) and $\mathrm{C}_{\mathrm{s}}=$ Heavy metal concentration in soil ( $\mathrm{mg} \mathrm{kg}^{-1} \mathrm{~d}$.w.). The Translocation Factor (TF) represents the quotient between the concentration of the metal in the aerial and root organs [30] and indicates the efficiency of the plant in translocating the accumulated metal from its roots to shoots [8]. The translocation factor (TF) was estimated as TF $=C_{a p} / C_{r}$, where $C_{a p}=$ Heavy metal concentration in aerial part (leaves and flowers) ( $\mathrm{mg} \mathrm{kg}^{-1}$ d.w.) and $\mathrm{C}_{\mathrm{r}}=$ Heavy metal concentration in roots ( $\mathrm{mg} \mathrm{kg}^{-1}$ d.w.).

\subsection{Soil Pollution Index}

In order to evaluate the degree of contamination of the soils studied we calculated the index used by Kwon and Lee [31] and in particular by Mendoza et al. [32] for the MRB. It is defined as follows:

$C_{f}=\frac{C_{m}}{C_{r e f}}$

where, $C_{f}$ is the contamination factor, $C_{m}$ is the concentration of the metal under study in the soil and $C_{\text {ref }}$ is the concentration of this metal in the soil used as reference; and:

$D_{c}=\sum C_{f}$

where $D_{c}$ is the soil contamination index and represents the sum of each $C_{f}$ measured in the soil. The reference soil used in this work was the same used by Mendoza et al. [32].

\subsection{Statistical Analysis}

Pearson correlation coefficients were calculated using R 3.5.0 [33]. The correlations were calculated for three data sets (riparian soil, water and plant tissue), as well as for each analyzed element in the different matrix. Correlation was assumed to be statistically significant at $p<0.05$. 


\section{Results and Discussion}

\subsection{Heavy Metals in the Water Column}

The mean concentration of the elements analyzed in water is shown in Table 1. Of the five metals analyzed in water, only $\mathrm{Cr}$ exceeded the limits established by the argentine Resolution 283/2019 for the protection of aquatic life [24]. The concentrations obtained followed the same trend as the historical values of the monitoring carried out by ACUMAR between 2008 and 2018 [25] for all metals except $\mathrm{Pb}$ where it was not detected.

\subsection{Heavy Metals in the Riparian Soil}

The concentrations of heavy metals in riparian soil were found in the following order: $\mathrm{Cr}>\mathrm{Zn}>\mathrm{Cu}>\mathrm{Pb}>\mathrm{Ni}$ (Table 2). The main contaminating metal found in the soils was $\mathrm{Cr}$, which is related to tanneries, one of the main economic activities that have been developed in the basin since 1895 [34].
Table 1 Ranges of mean concentrations of metals in water $\left(\mathrm{mg} \mathrm{L}^{-1}\right)$ from sites of Matanza-Riachuelo River $(n=3)$. Detection and quantification limits $\left(\mathrm{mg} \mathrm{L}^{-1}\right)$
Table 2 Ranges of mean concentrations of metals in riparian soils $\left(\mathrm{mg} \mathrm{kg}^{-1}\right.$ d.w.) from sites of MatanzaRiachuelo River $(n=3)$. Detection and quantification limits ( $\mathrm{mg} \mathrm{kg}^{-1} \mathrm{~d}$.w.). Values of contamination factor $\left(C_{f}\right)^{a}$ and degree of contamination $\left(D_{c}\right)^{b}$ by metals for the reference soil for contamination assessment of the soil sites associated to the plants studied

\begin{tabular}{lllllll}
\hline & & $\mathrm{Cr}$ & $\mathrm{Cu}$ & $\mathrm{Zn}$ & $\mathrm{Ni}$ & $\mathrm{Pb}$ \\
\hline Water & Min & 0.031 & 0.030 & 0.049 & 0.009 & $\mathrm{ND}^{\mathrm{a}}$ \\
& Max & 0.091 & 0.030 & 0.101 & 0.013 & \\
& Mean & 0.059 & 0.030 & 0.068 & 0.010 & \\
& $\mathrm{~S} . \mathrm{E}$. & 0.017 & 0.000 & 0.016 & 0.001 & \\
Detection limit & & 0.012 & 0.010 & 0.005 & $0.002^{\mathrm{b}}$ & $0.002^{\mathrm{b}}$ \\
Quantification limit $^{\text {Argentine legislation }}{ }^{\mathrm{c}}$ & & 0.050 & 0.050 & 0.030 & $0.005^{\mathrm{b}}$ & $0.010^{\mathrm{b}}$ \\
Historical values $^{\mathrm{d}}$ & & $<0.020$ & $<0.009$ & $<0.120$ & $<0.250$ & $<0.002$ \\
& Min & 0.002 & 0.005 & 0.003 & 0.001 & 0.0002 \\
& Max & 0.485 & 0.100 & 0.319 & 0.400 & 0.102 \\
& Mean & 0.058 & 0.020 & 0.093 & 0.022 & 0.012 \\
& S.E. & 0.007 & 0.002 & 0.017 & 0.006 & 0.002 \\
\hline
\end{tabular}

${ }^{\mathrm{a}} N D$ no detection level

${ }^{b}$ Determined by graphite furnace [29]

'Reference value refers to ACUMAR Resolution 283/2019 [24] (mg L ${ }^{-1}$ )

${ }^{\mathrm{d}}$ Historical values reported by the Autoridad de Cuenca Matanza-Riachuelo (ACUMAR) in its hydrological data base (2008-2018 period) [25]

\begin{tabular}{lllllll}
\hline & & $\mathrm{Cr}$ & $\mathrm{Cu}$ & $\mathrm{Zn}$ & $\mathrm{Ni}$ & $\mathrm{Pb}$ \\
\hline Riparian soils & Min & 1548.8 & 336.5 & 1388.8 & 55.2 & 172.4 \\
& Max & 3025.6 & 426.9 & 1693.3 & 65.2 & 287.5 \\
& Mean & 2225.2 & 366.8 & 1495.1 & 61.0 & 238.9 \\
& $\mathrm{~S} . \mathrm{E}$. & 430.8 & 30.1 & 99.2 & 3.0 & 34.4 \\
Detection limit & & 0.5 & 0.4 & 0.2 & 0.1 & 0.1 \\
Quantification limit & & 2.0 & 2.0 & 1.2 & 0.2 & 0.4 \\
PEL $^{\text {d }}$ & & 90 & 197 & 315 & $\mathrm{NV}$ & 91 \\
Argentine legislation $^{\mathrm{f}}$ & & 250 & 100 & 500 & 100 & 500 \\
Index contamination in soil $^{\text {Index }}$ & $\mathrm{C}_{\mathrm{f}}^{\mathrm{a}}$ & 117 & 32 & 20 & $\mathrm{NV}$ & 8 \\
& $\mathrm{D}_{\mathrm{c}}^{\mathrm{b}}$ & $177 \pm 25$ & & & & \\
\hline
\end{tabular}

${ }^{\mathrm{a}} \mathrm{C}_{\mathrm{f}}<1$ low contamination factor; $\mathrm{C}_{\mathrm{f}} 1-3$ moderate contamination factor, $\mathrm{C}_{\mathrm{f}} 3-6$ high contamination factor, $C_{f}>6$ very high contamination factor

${ }^{b} D_{c}<6$ low degree of contamination; $6<D_{c}<12$ moderate degree of contamination; $12<D_{c}<24$ considerable degree of contamination; $D_{c}>24$ very high degree of contamination $D_{c}=\Sigma C_{f} \pm S$.E

'Reference soil ( $\mathrm{mg} \mathrm{kg}^{-1}$ ): $\mathrm{Cr}$ 19.3, Cu 23.0, Pb 31.0, Zn 74.1

${ }^{d}$ Probable effect level (PEL) of the Canadian Council of Minister of the Environment (CCME) [36]

${ }^{\mathrm{e}} N V$ no value

${ }^{f}$ Decree 831/93, Annex II, Table 2, regulatory of the Argentinian National Law of Hazardous Waste No. 24051 (Soil quality guide levels for Residential use [35] [mg kg-1 d.w.]) 
A comparative analysis of the results was carried out with the Argentine legislation (guide levels of land quality for residential use [35] (Table 2) due to the fact that there are urban settlements on the riverbanks. With the exception of $\mathrm{Pb}$ and $\mathrm{Ni}$, the values of metals found in the riparian soil exceed those allowed for residential use. Thus, these sites present significant risk to human health and the biota, and confirm the deterioration of the environmental quality.

In turn, the contamination degree index $\left(D_{c}\right)$, calculated from Eq. (2), categorizes this soil as very high degree of contamination (Table 2), consistent with what is reported by Mendoza et al. [32].

On the other hand, to evaluate the level of toxicity, the results were compared with the Probable Effect Level (PEL) of the Canadian Council of Minister of the Environment (CCME) [36], which is defined as the level above which adverse biological effects are most likely to occur. For all metals (except Ni where there are no CCME values) the concentrations exceed the PEL (Table 2).

The main reservoir of heavy metals in the system was the soil. The presence of metals in riparian soils above the reference values are a direct consequence of effluent dumping without adequate treatment. The accumulation of metals in sediments has also been reported by other authors in similar environments [37-39].

\subsection{Heavy Metals in Plant Tissue}

Although metals can accumulate in plants both through root [40] and through foliar absorption [41, 42], the transfer of metals from the soil root is the main route by which heavy metals enter the plant [43]. Given the associated difficulty in discriminating these two pathways of entry as well as the high concentration of metals present in the soil, this study was approached from the premise that the metals found in the plant tissue came from the soil.

S. montevidensis absorbed the metals studied in the following order: $\mathrm{Zn}>>\mathrm{Cu}>\mathrm{Cr}>\mathrm{Ni}=\mathrm{Pb}$, similar results were reported by [44] for this species. However, the collected individuals for this study were in bloom, without chlorotic leaves or signs of stress. Concentrations of $\mathrm{Pb}$ and $\mathrm{Ni}$ measured in the total plant exceeded reference levels for plant species in general [45] (Table 3). On the other hand, the concentrations of $\mathrm{Cr}, \mathrm{Zn}$ and $\mathrm{Cu}$ in total plant were above the limits considered excessive or toxic [45] (Table 3). The ability to tolerate and accumulate these metals without visible damage, could be provided by the presence of this species in an environment polluted with these metals for more than 100 years. Similar results were found by Demarco et al. [23]. They found individuals of $S$. montevidensis with concentrations of $\mathrm{Cu}, \mathrm{Mn}$ and $\mathrm{V}$ higher than the levels considered toxic, confirming the ability of this species to grow in deteriorated environments and in the presence of different contaminants. In the MRB, de
Table 3 Ranges of mean concentrations of metals [mg kg ${ }^{-1}$ d.w.] in belowground plant parts, stem and leaves, flowers and total plant of Sagittaria montevidensis from sites Matanza-Riachuelo River $(n=3)$. Detection and quantification limits and reference value $\left[\mathrm{mg} \mathrm{kg}^{-1} \mathrm{~d} . \mathrm{w}\right.$.] basis [45]

\begin{tabular}{|c|c|c|c|c|c|c|}
\hline \multicolumn{2}{|c|}{ Organs of Sagittaria montevidensis } & \multirow{2}{*}{$\frac{\mathrm{Cr}}{19.6}$} & \multirow{2}{*}{$\frac{\mathrm{Cu}^{\mathrm{a}}}{41.6}$} & \multirow{2}{*}{$\frac{\mathrm{Zn}^{\mathrm{a}}}{195.2}$} & \multirow{2}{*}{$\begin{array}{l}\mathrm{Ni} \\
7.2\end{array}$} & \multirow{2}{*}{$\frac{\mathrm{Pb}}{9.3}$} \\
\hline Belowground plant parts & Min & & & & & \\
\hline & Max & 46.5 & 59.2 & 339.3 & 10.7 & 25.5 \\
\hline & Mean & 30.8 & 47.9 & 251.8 & 8.9 & 16.7 \\
\hline & S.E. & 8.1 & 5.7 & 44.4 & 1.0 & 4.7 \\
\hline \multirow[t]{4}{*}{ Stem and leaves } & Min & 9.3 & 51.5 & 103.6 & 5.8 & 0.9 \\
\hline & Max & 11.6 & 73.8 & 149.0 & 6.9 & 1.8 \\
\hline & Mean & 10.4 & 62.1 & 133.3 & 6.3 & 1.5 \\
\hline & S.E. & 1.1 & 6.5 & 14.9 & 0.3 & 0.3 \\
\hline \multirow[t]{4}{*}{ Flowers } & Min & 0.0 & 24.1 & 40.9 & 2.0 & 0.5 \\
\hline & Max & 1.7 & 49.8 & 50.4 & 3.3 & 0.8 \\
\hline & Mean & 0.6 & 33.3 & 46.5 & 2.7 & 0.6 \\
\hline & S.E. & 0.6 & 8.3 & 2.9 & 0.3 & 0.1 \\
\hline \multirow[t]{4}{*}{ Total plant } & Min & 19.6 & 110.8 & 392.6 & 16.5 & 11.0 \\
\hline & Max & 59.8 & 165.1 & 483.7 & 19.7 & 27.5 \\
\hline & Mean & 38.3 & 129.1 & 426.4 & 17.6 & 18.7 \\
\hline & S.E. & 11.7 & 18.0 & 28.8 & 1.0 & 4.8 \\
\hline Detection limit & & 0.6 & 0.5 & 0.3 & 0.1 & 0.1 \\
\hline Quantification limit & & 2.5 & 2.5 & 1.5 & 0.3 & 0.5 \\
\hline \multirow{2}{*}{$\begin{array}{l}\text { Reference values for spe- } \\
\text { cies in general }\end{array}$} & Sufficient or normal & $0.1-0.5$ & $5-30$ & $27-150$ & $0.1-5$ & $5-10$ \\
\hline & Excessive or toxic & $5-30$ & $20-100$ & $100-400$ & $10-100$ & $30-300$ \\
\hline
\end{tabular}

${ }^{\text {a Micronutrients }}$ 
Cabo et al. [46] and Mendoza et al. [32] found levels of $\mathrm{Cr}, \mathrm{Cu}$ and $\mathrm{Zn}$ in individuals of Tradescantia fluminensis and $\mathrm{Cr}, \mathrm{Cu}, \mathrm{Zn}$ and $\mathrm{Pb}$ in individuals of Hydrocotyle bonariensis and Eleocharis montana, respectively, higher than reference values of terrestrial plants in unpolluted areas. These individuals showed tolerance to high levels of contamination in the sites belonging to the basin studied in this work. Plants adapt to stress situations such as those caused by the presence of metals in the environment by developing detoxification mechanisms such as chelation and sub-cellular compartmentalization [47]. Although this has been described mainly for species of the family Brassicaceae and very little is known about this type of behavior in native plants of other families, it could be expected that the mechanisms are similar. Plants develop mechanisms to control the uptake and accumulation of metal through the overexpression of genes related to the tolerance and accumulation of metals in their tissues [48]. Overexpression of these genes is more likely to occur in the S. montevidensis population because it has been in contact with elevated levels of heavy metals for more than 100 years explaining the tolerance to contamination observed for S. montevidensis in MRB. The phenotypic plasticity of the vegetative and reproductive features of this genus should be highlighted. For example, [49] reported that Sagittaria latifolia populations are self-compatible and monoecious or dioecious occurring in wetland habitats where disturbance and competition, respectively, are most important. These contrasting life-history strategies allow the species to respond to variations in environmental conditions and disturbances [14] as in the case of S. montevidensis resistance to herbicides (penoxsulam and betazon) [50] or to metal contamination as reported by Demarco et al. [23] and in the present paper.

Although concentrations of $\mathrm{Cr}$ in the riparian soil were higher than those of the rest of the metals, higher concentrations of $\mathrm{Cu}$ and $\mathrm{Zn}$ were determined in the tissues, since they are micronutrients and the organisms need them for their growth and metabolic functions [51]. In contrast, $\mathrm{Cr}, \mathrm{Pb}$ and $\mathrm{Ni}$ were incorporated to a lesser extent by the plant. Both $\mathrm{Cr}$ and $\mathrm{Pb}$ have no known biological functions for physiological and biochemical processes in cells and are toxic to living organisms even when they are present in low concentrations [52].

$B C F$ values $<0.5$ were obtained for all metals. Although the plant incorporated all the metals in its biomass, it may not be reflected in BCF values, due to the high concentration of the metals in the soil. Ali et al. [8] described that high metal concentrations in soil could result in a $\mathrm{BCF}<1$ even though the plant had incorporated high concentrations, for example soils with $3000 \mathrm{mg} \mathrm{kg}^{-1} \mathrm{Ni}$ and $2000 \mathrm{mg} \mathrm{kg}^{-1} \mathrm{Ni}$ in a plant. Kickhöfel Ferrer et al. [16] worked with this same species in sites contaminated by heavy metals and they obtained a $B C F<1$ in those sites where the concentration of $\mathrm{Zn}$ was higher than $200 \mathrm{mg} \mathrm{kg}^{-1}$ d.w. and the concentration of $\mathrm{Cu}$ was higher than $18 \mathrm{mg} \mathrm{kg}^{-1}$ d.w. In contrast, they obtained a BCF $>1$ when $\mathrm{Zn}$ concentration in the soil was $26.7 \pm 0.7 \mathrm{mg} \mathrm{kg}^{-1}$ d.w. and also in soils which $\mathrm{Ni}$ concentration range was between $2.3-5.1 \mathrm{mg} \mathrm{kg}^{-1} \mathrm{~d}$.w. For sites with a high degree of contamination within the MRB, de Cabo et al. [46] obtained BCF values of 1 for $\mathrm{Zn}, \mathrm{Pb}, \mathrm{Cu}$ and $\mathrm{Ni}$ in T. fluminensis, while for $\mathrm{Cr}$ they obtained values of 6.5 .

S. montevidensis showed a low level of translocation towards the aerial structures ( $\mathrm{TF}<1$ ) was observed for $\mathrm{Cr}$, $\mathrm{Pb}$ and $\mathrm{Zn}$. This result is in line with Baker [11], for which metal excluders are plants which effectively limit the levels of heavy metal translocation within them and maintain relatively low levels in their shoot over a wide range of soil levels; however, they can still contain large amounts of metals in their roots. TF $>1$ was obtained for $\mathrm{Cu}$ and $\mathrm{Ni}$, behaving as a metal accumulator for these elements. The TFs for $\mathrm{Cu}, \mathrm{Ni}$ and $\mathrm{Zn}$ obtained in this work were lower than those reported by Kickhöfel Ferrer et al. [16] for this species. For $\mathrm{Cr}$ and $\mathrm{Pb}$ they were similar to those detected by Demarco et al. [23] (0.4 and 0.5, respectively).

Table 3 shows the distribution of metals in the plant's organs. The analyzed metals were found in all plant structures. $\mathrm{Cr}, \mathrm{Zn}, \mathrm{Ni}$ and $\mathrm{Pb}$ were mainly accumulated in the root. The lowest levels of metals were detected in the flowers. Cu was accumulated mainly in the aerial biomass. The translocation of $\mathrm{Cu}$ was due to the fact that it is an essential micronutrient for plant metabolism [53] and it is involved in the processes of photosynthesis, respiration and protein metabolism [51], although its excessive accumulation in plant tissue can be toxic for plants [54].

$\mathrm{Zn}$ was the metal that was mostly incorporated by the plant (Table 3). This metal is an essential micronutrient for plants. In contrast to $\mathrm{Fe}, \mathrm{Mn}, \mathrm{Cu}$ and $\mathrm{Mo}, \mathrm{Zn}$ is a transition element that is not subject to valence changes and it is present in plants only as Zn (II) [55]. Within the main functions of this micronutrient are stress tolerance, reproductive growth (induction to flowering, pollination, fruit establishment) and to be a constituent of cell walls and membrane. The highest concentration of this metal was found in the roots $\left(252 \pm 44 \mathrm{mg} \mathrm{kg}^{-1}\right.$ d.w.) and it was distributed within the plant in the following decreasing order: root $>$ stem and leaves $>$ flower. Kickhöfel Ferrer et al. [16] found $\mathrm{Zn}$ values in roots in a range between 41.3 and $168.8 \mathrm{mg} \mathrm{kg}^{-1}$ d.w. while Demarco et al. [23] found concentrations of $235 \pm 33 \mathrm{mg} \mathrm{kg}^{-1}$ d.w. in the total plant.

$\mathrm{Pb}$ is not an essential element for plant growth [56]. It is firmly bound to soil particles from immobilisation processes such as adsorption, precipitation, complexation and redox reactions [57] making it poorly bioavailable. Also, its transport from roots to aerial structures is 
usually negligible in most plants [58]. Once this metal has penetrated roots, it can accumulate there and only a small fraction is translocated to aerial parts of the plant [59]. The results of this work agree with these authors since the highest concentration of $\mathrm{Pb}$ was found in the roots ( $16.7 \pm 4.7 \mathrm{mg} \mathrm{kg}^{-1}$ d.w.) (Table 3). The concentration of $\mathrm{Pb}$ assimilated by the whole plant was $18.7 \pm 4.8 \mathrm{mg} \mathrm{kg}^{-1} \mathrm{~d}$.w. Demarco et al. [23] have reported similar concentrations $\left(13.7 \pm 3.4 \mathrm{mg} \mathrm{kg}^{-1}\right.$ d.w. $)$ in the $S$. montevidensis tissue.

$\mathrm{Ni}$ is an essential element in plant metabolism; however at excessive levels many biological processes can be disrupted $[51,52]$ including photosynthesis and transpiration [45]. The mobility of $\mathrm{Ni}$ in plants varies from mobile in some plants to immobile in other species [55]. We found that Ni has mobility within S. montevidensis despite of the maximum concentration of $\mathrm{Ni}$ was observed in the root $\left(17.7 \pm 1.0 \mathrm{mg} \mathrm{kg}^{-1}\right.$ d.w.) (Table 3).

$\mathrm{Cr}$ is an element considered toxic to plants [53]. The highest concentration of this metal was found in the root $\left(30.8 \pm 8.1 \mathrm{mg} \mathrm{kg}^{-1}\right.$ ) (Table 3). It is probable that the plant concentrates and confines $\mathrm{Cr}$ in the roots as a defense strategy to face the toxicity of this metal $[51,60,61]$. Other authors have also recorded higher concentrations of this metal in roots in emerging aquatic plant species than in other [62]. However, concentrations of this metal were also observed in the aerial part $\left(10.4 \pm 1.1 \mathrm{mg} \mathrm{kg}^{-1}\right.$ d.w.). Once it is translocated to the aerial tissues, the plant might activate physiological and biochemical mechanisms to counteract its toxicity as has been observed for other species [63].
The results obtained indicate that this species can be used to phytoremediate soils and sediments. It showed ability to phytoextract $\mathrm{Cu}$ and $\mathrm{Ni}$ from the soil and translocate them to the aerial part, facilitating their elimination by harvest. In highly contaminated soils as the study sites, the plants that can extract and translocate metals could be considered accumulator although the BCFs were less than 1. In fact, the values found in tissue were excessive or toxic. For $\mathrm{Cr}, \mathrm{Pb}$ and $\mathrm{Zn}$, the plants behaved as metal excluders since it accumulated them in its underground structures and practically did not translocate them to the aerial biomass as a defense mechanism of the photosynthetic structures $[8,64]$. Therefore, this species can be used to stabilize $\mathrm{Cr}, \mathrm{Pb}$ and $\mathrm{Zn}$ in riparian soil by preventing their passage by runoff into the water column [65], limiting mobility to groundwater and decreasing their bioavailability.

\subsection{Comparison of Metal Contents in Water, Riparian Soil, and Plants}

The riparian zone is a major part of most riverine systems, providing ecotones with high biodiversity [66]. This in turn is influenced by the associated vegetation exposed to the flood pulse of the river. Therefore, vegetation, riparian soil, and water are in close contact and interaction. In this sense, the Pearson correlation coefficients of the heavy metals in the three matrices were evaluated (Fig. 3). The metal content in the plant tissue correlated positively with the metals present in the water $(r=0.560, p<0.05)$. The metals in the soil showed a positive but not significant $(r=0.340, p>0.05)$ trend with those incorporated in

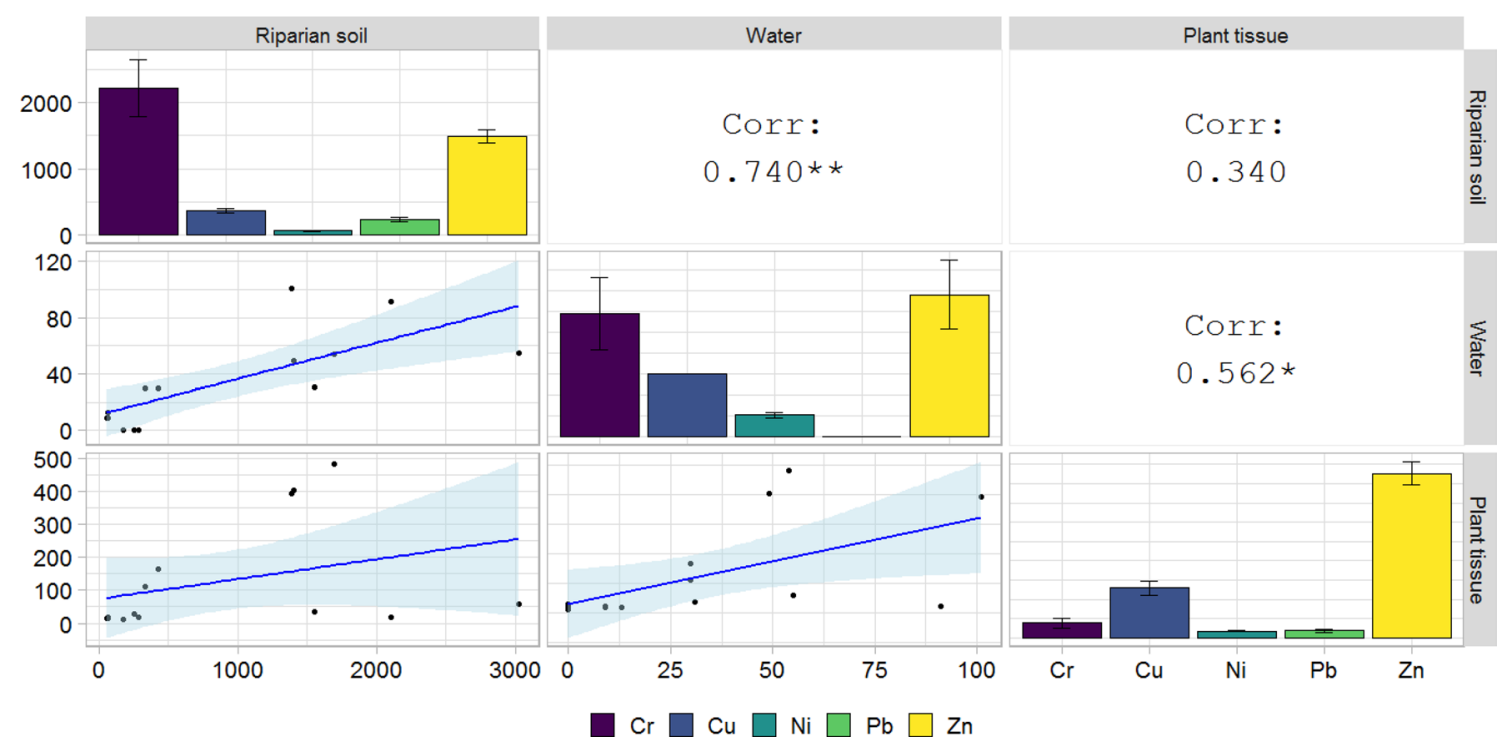

Fig. 3 Relationship of the total content of heavy metals ( $\mathrm{Cr}$ (violet), $\mathrm{Cu}$ (blue), $\mathrm{Ni}$ (light blue), Pb (green), and Zn (yellow)) in riparian soil, plant tissue (Sagittaria montevidensis), and water. $\left({ }^{*}\right)$ indicates sig- nificant correlations $(p<0.05),\left({ }^{* *}\right)$ indicates significant correlations $(p<0.01)$. Distribution of heavy metals in each matrix: riparian soil (mg kg ${ }^{-1}$ d.w.), water $\left(\mu \mathrm{g} \mathrm{L}^{-1}\right)$, and plant tissue $\left(\mathrm{mg} \mathrm{kg}^{-1}\right.$ d.w.) 
the plant tissue while the concentration of metals in the water correlated positively with that of the riparian soil $(r=0.740, p<0.01)$. The presence of metals in the riparian soil is given by the influence that the aquatic system has on the terrestrial one (and vice versa), the discharge of effluents without an adequate treatment not only contaminated the body of water but also impacted the riverbank. The correlation analysis responds to the close interconnection between the soil and riparian vegetation with the river system.

Likewise, the low correlation between the concentrations found in the plants with respect to those present in the riparian soil shows a trend that supports the observed results, since the percentage of metal uptake by the plants with respect to that present in the soil varies for each element. The uptake percentages were $2 \% \mathrm{Cr} ; 35 \% \mathrm{Cu} ; 29 \%$ $\mathrm{Zn}$ and $\mathrm{Ni}$ and $8 \% \mathrm{~Pb}$.

\section{Conclusions}

The riparian zone is a major part of most riverine systems. Provide many ecological functions and services as biological corridors and buffer zones to retain pollutants that may enter from urban runoff while mitigating flooding. In the particular case of MRB, the lower basin is the most contaminated with $\mathrm{Cr}, \mathrm{Ni}, \mathrm{Zn}, \mathrm{Pb}$, and $\mathrm{Cu}$ as a result of the industrial impact and effluent discharge without adequate treatment. In this sense, aquatic vegetation plays a key role in the retention and immobilization of heavy metals. S. montevidensis proved to be a native species with the capacity to retain, immobilize, and tolerate these metals. Despite the damage that heavy metals can cause in plant species, S. montevidensis analyzed specimens that did not present signs of stress and having completed their phenological states. All the metals were uptake by the S. montevidensis. It is an accumulator for $\mathrm{Cu}$ and $\mathrm{Ni}$, while it behaves as a metal excluder for $\mathrm{Cr}, \mathrm{Pb}$, and $\mathrm{Zn}$. $\mathrm{Zn}$ and $\mathrm{Cu}$ were the most assimilated elements because they are essential micronutrients for plant development. Cu was the only metal that was distributed in different organs. Despite its toxicity, concentrations of $\mathrm{Ni}$ and $\mathrm{Cr}$ were detected in the aerial part while $\mathrm{Pb}$ was practically confined to the roots. From an environmental point of view, this native species is adapted to the degraded environment in which it grows. In this context, the preservation and revegetation of this species in the riparian areas constitute a sustainable alternative for ecological restoration due to its tolerance and its availability to accumulate and stabilize heavy metals present in the riparian soil.

Acknowledgements The authors wish to thank Esteban Dermeguerditchian and Oscar Cantarella for their collaboration in the sampling and Leandro laconis for his help in the processing of the samples.

Funding This work was financed by the Instituto Nacional del Agua (Expte. 16287/16) and by the projects PICT-2017-2638 Agencia Nacional de Promoción Científica y Tecnológica (ANPCyT) and PIP 11220170100082 Consejo Nacional de Investigaciones Científicas y Técnicas (CONICET).

\section{Compliance with ethical standards}

Conflict of interest The content of this manuscript has not been published or submitted for publication, in whole or in part, elsewhere. There are no conflicts of interest to declare.

\section{References}

1. Institute B (2007) The world's worst polluted places: the top ten of the dirty thirty. Final Report

2. Magdaleno A, de Cabo L, Arreghini S, Salinas C (2014) Assessment of heavy metal contamination and water quality in an urban river from Argentina. Braz J Aquat Sci Technol 18:113-120

3. Cattaneo MP, Sardi EML (2013) Evolución de la calidad del agua de la cuenca Matanza-Riachuelo. Cien Tecnol 2013:251-278

4. Salazar MJ, Pignata ML (2014) Lead accumulation in plants grown in polluted soils. Screening of native species for phytoremediation. J Geochem Explor 137:29-36. https://doi. org/10.1016/j.gexplo.2013.11.003

5. Becerril JM, Barrutia O, Plazaola JIG et al (2007) Especies nativas de suelos contaminados por metales: aspectos ecofisiológicos y su uso en fitorremediación. Rev Ecosist 16

6. Jackson LJ (1998) Paradigms of metal accumulation in rooted aquatic vascular plants. Sci Total Environ 219:223-231. https:// doi.org/10.1016/S0048-9697(98)00231-9

7. Kloke A, Sauerbeck DR, Vetter H (1994) Study of the transfer coefficient of cadmium and lead in ryegrass and lettuce. In: Changing metal cycles and human health. Springer, Berlin, $p$ 113

8. Ali H, Khan E, Sajad MA (2013) Phytoremediation of heavy metals-concepts and applications. Chemosphere 91:869-881. https://doi.org/10.1016/j.chemosphere.2013.01.075

9. Sheoran V, Sheoran AS, Poonia P (2010) Role of hyperaccumulators in phytoextraction of metals from contaminated mining sites: a review. Crit Rev Environ Sci Technol 41:168-214. https:// doi.org/10.1080/10643380902718418

10. Ghosh M (2005) A review on phytoremediati on of heavy metals and utilization of its byproducts. Appl Ecol Environ Res 3:1-18

11. Baker AJM (1981) Accumulators and excluders-strategies in the response of plants to heavy metals. J Plant Nutr 3:643-654

12. Romero MI, Onaindia M (1995) Fullgrown aquatic macrophytes as indicators of river water quality in the northwest Iberian Peninsula. In: Annales botanici fennici. JSTOR, New York, pp 91-99

13. Zurayk R, Sukkariyah B, Baalbaki R, Ghanem DA (2001) Chromium phytoaccumulation from solution by selected hydrophytes. Int J Phytoremediation 3:335-350

14. Dorken ME, Barrett SCH (2004) Phenotypic plasticity of vegetative and reproductive traits in monoecious and dioecious populations of Sagittaria latifolia (Alismataceae): a clonal aquatic plant. J Ecol 92:32-44

15. Zhang J, Wen C, Chen M et al (2019) Antioxidant activities of Sagittaria sagittifolia L. polysaccharides with subcritical water extraction. Int J Biol Macromol 134:172-179. https://doi. org/10.1016/j.ijbiomac.2019.05.047 
16. Ferrer EMK, Betemps GR, da Rosa NN, Filho PJS (2017) Evaluation of the Sagittaria montevidensis Cham. \& Schltdl. as a bioindicator and phytoextractor of toxic metals. Ambiente Agua Interdiscip J Appl Sci 12:918

17. Smith JG (1895) A Revision of the North American Species of Sagittaria and Lophotocarpus. Mo Bot Garden Ann Rep 1895:27

18. Bogin C (1953) Revision of the genus Sagittaria (Alismataceae). Faculty of Pure Science, Columbia University

19. Soares DJ, Barreto RW, Braun U (2009) Brazilian mycobiota of the aquatic weed Sagittaria montevidensis. Mycologia 101:401-416

20. Feijoo C, Lombardo R (2007) Baseline water quality and macrophyte assemblages in Pampean streams: a regional approach. Water Res 41:1399-1410

21. van Oosterom MVL, Ocon C, Armendariz LC, Capitulo AR (2015) Structural and functional responses of the oligochaete and aeolosomatid assemblage in lowland streams: a one-way-pollutionmodelled ecosystem. J Limnol 74:1142

22. Basílico G, de Cabo L, Faggi A, Miguel S (2016) Low-tech alternatives for the rehabilitation of aquatic and riparian environments. Phytoremediation 2016:349-364

23. Demarco CF, Afonso TF, Pieniz S et al (2019) Phytoremediation of heavy metals and nutrients by the Sagittaria montevidensis into an anthropogenic contaminated site at Southern of Brazil. Int J Phytoremediation 21:1145-1152

24. ACUMAR InfoLEG - Ministerio de Justicia y Derechos Humanos Argentina. http://servicios.infoleg.gob.ar/infolegInternet/anexo s/330000-334999/334281/norma.htm. Accessed 13 Oct 2020

25. Base de Datos Hidrológicos. http://www.bdh.acumar.gov.ar/ bdh3/index_contenido.php. Accessed 13 Oct 2020

26. US. EPA (2007) Method 3015A (SW-846): Microwave assisted acid digestion of aqueous samples and extracts. Washington, DC

27. US. EPA (1996) Method 3052, Microwave assisted acid digestion of siliceous and organically based matrices. Test Methods for Evaluating Solid Waste

28. US. EPA (2007) Method 3051A (SW-846): microwave assisted acid digestion of sediments, sludges, and oils. Washington, DC

29. APHA (2018) WEF (2005) standard methods for the examination of water and wastewater. Washington DC

30. Mattina MI, Lannucci-Berger W, Musante C, White JC (2003) Concurrent plant uptake of heavy metals and persistent organic pollutants from soil. Environ Pollut 124:375-378. https://doi. org/10.1016/s0269-7491(03)00060-5

31. Kwon Y-T, Lee C-W (1998) Application of multiple ecological risk indices for the evaluation of heavy metal contamination in a coastal dredging area. Sci Total Environ 214:203-210. https:// doi.org/10.1016/S0048-9697(98)00069-2

32. Mendoza RE, García IV, de Cabo L et al (2015) The interaction of heavy metals and nutrients present in soil and native plants with arbuscular mycorrhizae on the riverside in the MatanzaRiachuelo River Basin (Argentina). Sci Total Environ 505:555-564

33. Team RC, Others (2013) R: a language and environment for statistical computing

34. Frecia GD (2017) Gestión del medio ambiente, el futuro de las curtiembres de la Cuenca Matanza Riachuelo. Universidad de Buenos Aires. Facultad de Ciencias Económicas

35. Decreto 831/93 del 23/04/93. http://servicios.infoleg.gob. ar/infoleglnternet/anexos/10000-14999/12830/norma.htm. Accessed 13 Oct 2020

36. CCME (2002) Canadian environmental quality guidelines, vol 2. Canadian Council of Ministers of the Environment, Winnipeg

37. Muniz P, Danulat E, Yannicelli B et al (2004) Assessment of contamination by heavy metals and petroleum hydrocarbons in sediments of Montevideo Harbour (Uruguay). Environ Int 29:1019-1028. https://doi.org/10.1016/S0160-4120(03)00096-5

38. Audry S, Schäfer J, Blanc G, Jouanneau J-M (2004) Fifty-year sedimentary record of heavy metal pollution $(\mathrm{Cd}, \mathrm{Zn}, \mathrm{Cu}, \mathrm{Pb})$ in the lot river reservoirs (France). Environ Pollut 132:413-426. https://doi.org/10.1016/j.envpol.2004.05.025

39. Sekabira K, Oryem Origa H, Basamba TA et al (2010) Assessment of heavy metal pollution in the urban stream sediments and its tributaries. Int J Environ Sci Technol 7:435-446

40. Pourrut B, Shahid M, Douay F et al (2013) Molecular mechanisms involved in lead uptake, toxicity and detoxification in higher plants. In: Gupta DK, Corpas FJ, Palma JM (eds) Heavy metal stress in plants. Springer, Berlin, pp 121-147

41. Kozlov MV (2005) Sources of variation in concentrations of nickel and copper in mountain birch foliage near a nickelcopper smelter at Monchegorsk, North-Western Russia: results of long-term monitoring. Environ Pollut 135:91-99. https:// doi.org/10.1016/j.envpol.2004.10.005

42. Schreck E, Foucault $Y$, Sarret $G$ et al (2012) Metal and metalloid foliar uptake by various plant species exposed to atmospheric industrial fallout: mechanisms involved for lead. Sci Total Environ 427-428:253-262. https://doi.org/10.1016/j.scito tenv.2012.03.051

43. Shahid M, Dumat C, Khalid S et al (2017) Foliar heavy metal uptake, toxicity and detoxification in plants: a comparison of foliar and root metal uptake. J Hazard Mater 325:36-58. https ://doi.org/10.1016/j.jhazmat.2016.11.063

44. Chatterjee $S$, Chetia M, Singh L et al (2011) A study on the phytoaccumulation of waste elements in wetland plants of a Ramsar site in India. Environ Monit Assess 178:361-371. https ://doi.org/10.1007/s10661-010-1695-x

45. Meharg AA (2011) Trace elements in soils and plants. 4th edition. By A. Kabata-Pendias. Boca Raton, FL, USA: CRC Press/ Taylor \& Francis Group (2010), pp. 548, US\$159.95. ISBN 9781420093681. Exp Agric 47:739-739

46. de Cabo LI, Faggi A, Miguel S, Basílico G (2019) Rehabilitación de las riberas de un sitio de la cuenca baja del río MatanzaRiachuelo. Biol Acuát. https://doi.org/10.24215/16684869e0 05

47. Yadav SK (2010) Heavy metals toxicity in plants: an overview on the role of glutathione and phytochelatins in heavy metal stress tolerance of plants. S Afr J Bot 76:167-179. https://doi. org/10.1016/j.sajb.2009.10.007

48. Cobbett C, Goldsbrough P (2002) Phytochelatins and metallothioneins: roles in heavy metal detoxification and homeostasis. Annu Rev Plant Biol 53:159-182. https://doi. org/10.1146/annurev.arplant.53.100301.135154

49. Dorken ME, Barrett SCH (2003) Life-history differentiation and the maintenance of monoecy and dioecy in Sagittaria latifolia (Alismataceae). Evolution 57:1973-1988

50. Moura DS, Noldin JA, Galon L et al (2015) Multiple resistance of Sagittaria montevidensis biotypes to acetolactate synthase and photosystem ii inhibiting herbicides. Planta Daninha 33:779-786. https://doi.org/10.1590/S0100-835820150004000 16

51. Ahmad P (2016) Plant metal interaction: emerging remediation techniques. Elsevier, Amsterdam

52. Salt DE, Blaylock M, Kumar NP et al (1995) Phytoremediation: a novel strategy for the removal of toxic metals from the environment using plants. Biotechnology 13:468-474. https://doi. org/10.1038/nbt0595-468

53. Bonanno G, Lo Giudice R (2010) Heavy metal bioaccumulation by the organs of Phragmites australis (common reed) and their potential use as contamination indicators. Ecol Indic 10:639-645

54. Mishra VK, Tripathi BD (2008) Concurrent removal and accumulation of heavy metals by the three aquatic macrophytes. Bioresour Technol 99:7091-7097. https://doi.org/10.1016/j.biort ech.2008.01.002

55. Kyrkby E, Römheld V (2007) Micronutrientes en la fisiología de las plantas: funciones, absorción y movilidad, Quito 
56. Demirezen D, Aksoy A (2006) Common hydrophytes as bioindicators of iron and manganese pollutions. Ecol Indic 6:388-393. https://doi.org/10.1016/j.ecolind.2005.04.004

57. Mahar A, Wang P, Ronghua LI, Zhang Z (2015) Immobilization of lead and cadmium in contaminated soil using amendments: a review. Pedosphere 25:555-568

58. Prasad MN, Strzalka K (2013) Physiology and biochemistry of metal toxicity and tolerance in plants. Springer, Cham

59. Shahid M, Pinelli E, Pourrut B et al (2011) Lead-induced genotoxicity to Vicia faba L. roots in relation with metal cell uptake and initial speciation. Ecotoxicol Environ Saf 74:78-84. https:// doi.org/10.1016/j.ecoenv.2010.08.037

60. Memon AR, Aktoprakligil D, Özdemir A, Vertii A (2001) Heavy metal accumulation and detoxification mechanisms in plants. Turk J Bot 25:111-121

61. Hall JL (2002) Cellular mechanisms for heavy metal detoxification and tolerance. J Exp Bot 53:1-11

62. Chandra P, Kulshreshtha K (2004) Chromium accumulation and toxicity in aquatic vascular plants. Bot Rev 70:313-327

63. Prado C, Rosa M, Pagano E, Prado F (2013) Metabolic interconnectivity among alternative respiration, residual respiration, carbohydrates and phenolics in leaves of Salvinia minima exposed to $\mathrm{Cr}(\mathrm{VI})$. Environ Exp Bot 87:32-38

64. Melignani E, de Cabo LI, Faggi AM (2015) Copper uptake by Eichhornia crassipes exposed at high level concentrations. Environ Sci Pollut Res Int 22:8307-8315. https://doi.org/10.1007/s1135 6-014-3972-7

65. Mganga N, Manoko MLK, Rulangaranga ZK (2011) Classification of plants according to their heavy metal content around north Mara gold mine, Tanzania: implication for phytoremediation. Tanzan J Sci 37:1. https://doi.org/10.4314/tjs.v37i1

66. Pavlović P, Mitrović M, Đorđević D et al (2016) Assessment of the contamination of riparian soil and vegetation by trace metalsA Danube River case study. Sci Total Environ 540:396-409

Publisher's Note pringer Nature remains neutral with regard to jurisdictional claims in published maps and institutional affiliations. 